\title{
Targeting Brain Tissue Oxygenation in Traumatic Brain Injury
}

\author{
Ross P Martini MD, Steven Deem MD, and Miriam M Treggiari MD PhD MPH
}

\author{
Introduction \\ Pathophysiology of Secondary Brain Injury \\ The Brain Tissue Oxygen Monitor \\ Technical Aspects \\ What $\mathbf{P}_{\mathrm{btO}_{2}}$ Measures \\ Appropriate Placement of the Monitor \\ Complications \\ Association Between Brain Tissue Hypoxia and Outcome \\ Targeting Brain Tissue Oxygenation \\ Outcome of Management Guided by Brain Tissue Oxygenation \\ Summary
}

\begin{abstract}
The management of patients with traumatic brain injury has evolved in the last several years, due to the introduction of new, invasive monitoring devices. The ability to monitor parameters other than measurements related to pressures has generated substantial interest. Brain tissue oxygenation monitoring has been consistently shown to provide prognostic information, as indicated by poor prognosis associated with low brain tissue oxygen values. Furthermore, various physiologic manipulations, including increasing the $\mathbf{P}_{\mathrm{aO}}$, have been associated with an increase in brain tissue oxygenation. Whether brain-oxygenation-guided therapy results in improvement in outcomes is debatable. Retrospective studies suggest benefit, while prospective studies have shown a higher intensity of therapeutic interventions with no outcome differences. Data from high quality randomized trials are necessary to determine if brain-oxygenation-guided therapy is beneficial. An oxygen challenge (transient increase in $\mathrm{F}_{\mathrm{IO}_{2}}$ to 0.6 up to 1.0) to assess the responsiveness of the monitoring and ascertain the presence of technical malfunction is an accepted practice. Key words: oxygen; brain injury; trauma; brain; oxygenation. [Respir Care 2013;58(1):162-169. (C) 2013 Daedalus Enterprises]
\end{abstract}

\section{Introduction}

Traumatic brain injury (TBI) is a common cause of death and disability among adults, with a mortality as high

\footnotetext{
Dr Martini is affiliated with the Department of Anesthesiology and Perioperative Medicine, Oregon Health and Science University Hospital, Portland, Oregon. Drs Deem and Treggiari are affiliated with the Department of Anesthesiology and Pain Medicine, Harborview Medical Center, University of Washington School of Medicine, Seattle, Washington.
}

Dr Treggiari presented a version of this paper at the 50th RESPIRATORY CARE Journal Conference, "Oxygen," held April 13-14, 2012, in San Francisco, California. as $40 \%$ within the first 48 hours, and a $20 \%$ rate of severe disability. ${ }^{1}$ In survivors who reach the hospital, secondary ischemic injury to the brain is an important contributor to morbidity and mortality. ${ }^{2}$ Intensive care for patients with TBI is focused on monitoring for and preventing secondary hypoxic injury. Intracranial pressure (ICP) monitoring

\footnotetext{
Correspondence: Miriam M Treggiari MD PhD MPH, Department of Anesthesiology and Pain Medicine, Harborview Medical Center, University of Washington School of Medicine, Box 359724, Seattle WA 98104. E-mail: treggmm@u.washington.edu.
}

DOI: $10.4187 /$ respcare.01942 


\section{Targeting Brain Tissue Oxygenation in Traumatic Brain Injury}

remains the standard monitor in neurocritical care, but additional monitors for brain tissue oxygenation $\left(\mathrm{P}_{\mathrm{btO}_{2}}\right)$ are being increasingly utilized and investigated. The technical aspects of direct $\mathrm{P}_{\mathrm{btO}_{2}}$ monitoring, as well as a critical appraisal of the data regarding its use to guide treatment of patients with TBI, are the focus of this review.

\section{Pathophysiology of Secondary Brain Injury}

Brain oxygenation is dependent on the content of oxygen in the arterial blood, cerebral blood flow, and metabolic activity of brain tissue; all 3 of these components can be altered in patients with TBI. A more recent concept of impaired brain function induced by hypoxia and ischemia is referred to as "spreading depression." 3,4 After an initial hyperemic response to injury, delays in energy-dependent recovery lead to hypoperfusion in tissue at risk of damage (an inverse hemodynamic response, or spreading ischemia). Impaired autoregulation of blood flow to the brain, hypotension, hypoxemia, elevated ICP, and increased metabolic requirements of injured brain tissue can jointly result in tissue ischemia and infarction.

Systemic hypoxemia was identified as a potential contributor to secondary brain injury approximately 30 years ago. ${ }^{5}$ In 1993, Chesnut et al conducted a more detailed analysis of the effects of systemic hypoxia and hypotension on secondary brain injury, using data from the Traumatic Coma Data Bank. ${ }^{2}$ These authors found that both hypoxia $\left(\mathrm{P}_{\mathrm{aO}_{2}} \leq 60 \mathrm{~mm} \mathrm{Hg}\right)$ and hypotension (single systolic blood pressure $<90 \mathrm{~mm} \mathrm{Hg}$ ) were independently associated with significant increases in morbidity and mortality from severe head injury. However, neither the Miller nor Chesnut studies adequately accounted for the effect of severity of illness and the cause of hypoxemia on mortality. Patients with TBI are at risk for hypoxemia of multiple etiologies, including coexisting polytrauma and neurogenic pulmonary edema. A number of pulmonary complications associated with prolonged ICU stay and mechanical ventilation, such as acute lung injury/ARDS, pneumonia, and volume overload, are common in patients with TBI, and may contribute to hypoxemia. ${ }^{6,7}$ Furthermore, the development of pulmonary complications is associated with worse neurological outcome in patients with TBI. ${ }^{8}$ Thus, the precise role that hypoxemia/systemic hypoxia plays in outcome after TBI is unclear, due to the confounding effect of associated illness and injury.

Patients with TBI also often receive vasopressors to maintain cerebral perfusion, and vasopressors have been shown to be associated with increased incidence of acute lung injury. ${ }^{9}$ In at least one study, patients with a management protocol guided by $\mathrm{P}_{\mathrm{btO}_{2}}$ monitoring received significantly more vasopressors than those with ICP monitoring alone. ${ }^{10}$ It is worth mentioning that the $\mathrm{P}_{\mathrm{btO}_{2}}$ monitor

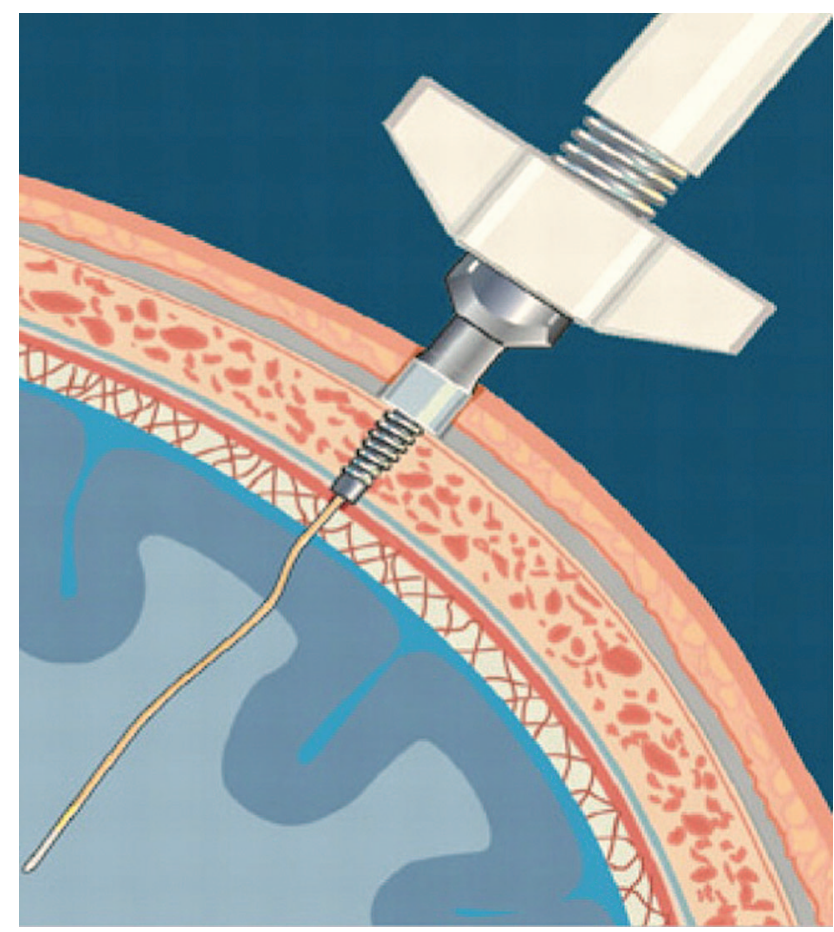

Figure. Coronal section illustrating the placement of the brain tissue oxygenation probe in the brain parenchyma. (Courtesy of Integra NeuroSciences.)

is not intended to be a monitor for hypoxemia or pulmonary complications of TBI.

Detection of brain tissue at risk for secondary injury is a paramount goal of the care of patients with TBI. One of the most studied methods for reduction of secondary injury is direct monitoring of ICP.11,12 Elevated ICP has been associated with poor outcome, and medical and surgical interventions to reduce ICP are associated with improvement in vital outcomes. ${ }^{13,14}$ However, ischemic injury can occur even in the absence of increased ICP, reflecting the flaw in the assumption that cerebral perfusion pressure is an adequate surrogate for cerebral blood flow. ${ }^{15-17}$ For this reason, several adjunct monitoring modalities have been developed to measure cerebral oxygenation, both directly and indirectly. One candidate for detection of ischemic secondary injury is the direct brain tissue oxygen monitor, which was recently included into the guidelines for management of severe TBI. ${ }^{18}$

\section{The Brain Tissue Oxygen Monitor}

\section{Technical Aspects}

The brain tissue oxygen monitor is a thin, metallic electrode that measures dissolved oxygen in a small area of brain tissue (Figure). Until recently, two commercial and technologically different probes for $\mathrm{P}_{\mathrm{btO}_{2}}$ monitoring have been available in the United States: one as a standalone 


\section{Targeting Brain Tissue Oxygenation in Traumatic Brain Injury}

tissue oxygenation sensor, recently upgraded to include ICP and brain temperature monitoring (Licox Brain Tissue Oxygen Monitoring, Integra LifeSciences, Plainsboro, New Jersey), and the other combined with an ICP monitor, temperature, and $\mathrm{pH} / \mathrm{P}_{\mathrm{CO}_{2}}$ sensor (Neurotrend, Diametrics Medical, High Wycombe, United Kingdom), which is no longer manufactured. The metallic tip of the Licox $\mathrm{P}_{\mathrm{btO}}$ monitor is a combination of 2 polarographic Clarke type electrodes covered in a semipermeable membrane at the tip of a flexible micro-catheter. In the presence of dissolved oxygen, one electrode reduces oxygen to water and generates an electrical difference, which is interpreted by the monitor as a particular value for oxygenation. While this is a quite precise and accurate way to measure dissolved oxygen, it is a highly localized measurement, with a sampling area of $7.1-15 \mathrm{~mm}^{2} .{ }^{19}$

\section{What $\mathbf{P}_{\mathrm{btO}_{2}}$ Measures}

What $\mathrm{P}_{\mathrm{btO}}$ represents in terms of the physiology of oxygen supply/demand in the brain remains under discussion. Most simply stated, the monitor measures free, dissolved oxygen. However, total oxygen delivery and cerebral oxygen metabolism are related to the oxygen content of blood, and only a small portion of blood oxygen content is dissolved:

$$
\mathrm{C}_{\mathrm{aO}_{2}}=\left(\text { hemoglobin } \times 1.36 \times \mathrm{S}_{\mathrm{aO}_{2}}\right)+\left(0.0031 \times \mathrm{P}_{\mathrm{aO}_{2}}\right)
$$

where $\mathrm{C}_{\mathrm{aO}}$ is the arterial oxygen content of the blood, and $\mathrm{S}_{\mathrm{aO}_{2}}$ is the arterial oxygen saturation.

Rosenthal et al recently evaluated the determinants of $\mathrm{P}_{\mathrm{btO}_{2}}$ in patients with severe TBI. ${ }^{20}$ Patients were given an oxygen challenge with $\mathrm{F}_{\mathrm{IO}_{2}}$ of 1.0 or an increase in mean arterial pressure, and changes in $\mathrm{P}_{\mathrm{btO}_{2}}$ in response to these 2 interventions were measured. $\mathrm{F}_{\mathrm{IO}_{2}}$ challenge linearly increased both the $\mathrm{P}_{\mathrm{aO}}$ and the $\mathrm{P}_{\mathrm{btO}_{2}}$, but had no effect on the cerebral metabolic rate for oxygen or oxygen delivery. Likewise, an increase in mean arterial pressure resulted in a small increase in cerebral blood flow and $\mathrm{P}_{\mathrm{btO}_{2}}$, but there was no change in the cerebral metabolic rate for oxygen. These observations suggest that the $\mathrm{P}_{\mathrm{btO}_{2}}$ is a measure primarily reflecting the oxygen dissolved in the blood and diffused in the cerebrospinal fluid and interstitial space, and not a measure of oxygen metabolism or delivery to the tissues. Gupta et al validated the measurements of the $\mathrm{P}_{\mathrm{btO}_{2}}$ sensor (Neurotrend) versus positron emission tomography in 16 patients, using $\mathrm{P}_{\mathrm{aCO}}$ reactivity. ${ }^{21}$ There was no correlation between end capillary $\mathrm{O}_{2}$ tension derived from $\mathrm{O}_{2}$ extraction fraction and $\mathrm{P}_{\mathrm{btO}_{2}}$ values; however, $\mathrm{P}_{\mathrm{btO}_{2}}$ changes in response to $\mathrm{P}_{\mathrm{aCO}}$ reactivity were highly correlated, suggesting that, while absolute values may not substitute for direct measures of oxygenation, change may be helpful in assessing responsiveness to therapeutic interventions. These observations call into question whether intervening on low $\mathrm{P}_{\mathrm{btO}_{2}}$ values can affect outcome. Some argument exists that higher partial pressures of oxygen could increase oxygen diffusion into tissues and overcome tissue barriers to diffusion, even without substantial changes in oxygen delivery. ${ }^{22}$ Hyperoxia remains of unclear benefit, however, and, in fact, experimentally may have deleterious effects on metabolically fragile areas of ischemic brain exposed to reperfusion-driven oxidative stress. ${ }^{23}$

\section{Appropriate Placement of the Monitor}

The monitor can be placed through the same burr hole as an ICP monitor (single lumen), and a new double catheter is now available to allow measurement of ICP, $\mathrm{P}_{\mathrm{btO}_{2}}$, and temperature simultaneously. As opposed to ICP measurement, the location of placement critically affects the values of $\mathrm{P}_{\mathrm{btO}_{2}}$ measured. Placement into an area of damaged brain, compared to placement into a relatively normal area, will result in vastly different data that fail to reflect global dissolved oxygen in either case. ${ }^{24}$ Placement on the more injured side of the brain will reflect the area at most risk for secondary injury. Placement on the less injured side could be extrapolated as a more global assessment of oxygenation, but it may not capture the environment of the tissue at highest risk for injury. ${ }^{25}$ Therapies to intervene on low $\mathrm{P}_{b_{t O}}$ values may also preferentially affect the uninjured brain tissue being monitored, and imply a false therapeutic benefit on penumbral brain issue. ${ }^{26}$ This highly localized view of the brain, along with the inability to provide information on oxygen consumption, is a major limitation of the monitor. Figure 1 illustrates the positioning of the $\mathrm{P}_{\mathrm{btO}_{2}}$ monitoring probe in the brain parenchyma.

\section{Complications}

Complications associated with the $\mathrm{P}_{\mathrm{btO}_{2}}$ monitor have been reported but are infrequent. It can be inserted through the same burr hole as an ICP monitor, so poses little additional risk. One of the first reports of experience with use of the $\mathrm{P}_{\mathrm{btO}_{2}}$ monitor reported a $1.7 \%$ rate of iatrogenic hematoma, which is similar to that of ICP monitoring. No reports of infection were made in that series, but there was a high rate of technical malfunction of the monitor $(13.6 \%)$ that necessitated replacement. ${ }^{27}$ After insertion there is a period of a few hours where the data collected by the monitor are inaccurate, due to local trauma associated with its insertion.

\section{Association Between Brain Tissue Hypoxia and Outcome}

Irrespective of the technical limitations of the monitor, the association between brain tissue hypoxia and poor outcome is well established. Both the depth and duration of episodes of brain tissue hypoxia have been associated with 


\section{Targeting Brain Tissue Oxygenation in Traumatic Brain Injury}

increased mortality and worse long-term neurological outcome in TBI and subarachnoid hemorrhage patients. ${ }^{28}$ Normal values for $\mathrm{P}_{\mathrm{btO}}$ in animal studies have been reported as between $25-30 \mathrm{~mm} \mathrm{Hg},{ }^{29}$ and thresholds for intervention in human patients with TBI have been established based on several observational studies. ${ }^{18}$ Higher mortality has been described with increasing duration of $\mathrm{P}_{\mathrm{btO}_{2}}$ values below $15 \mathrm{~mm} \mathrm{Hg}$, and instances of any duration of $\mathrm{P}_{\mathrm{btO}}$ below $6 \mathrm{~mm} \mathrm{Hg.}{ }^{30}$ In 1998, Bardt et al found that $\mathrm{P}_{\mathrm{btO}}$ values $<10 \mathrm{~mm} \mathrm{Hg}$ for $>30$ min were associated with $56 \%$ mortality, compared to $9 \%$ in those without. The likelihood of a good neurological outcome was similarly reduced to $22 \%$, compared with $73 \%$ in patients without prolonged brain tissue hypoxia. ${ }^{31}$ One recent review of the literature found a 4-fold increase in the odds of death or disability at 6 months in patients with $\mathrm{P}_{\mathrm{btO}_{2}}<10 \mathrm{~mm} \mathrm{Hg}$ at any time. ${ }^{32}$ It is therefore well established that low $\mathrm{P}_{\mathrm{btO}_{2}}$ is a strong indicator of poor prognosis. Given the strong association between low $\mathrm{P}_{\mathrm{btO}_{2}}$ and outcome, it is logical to question whether correcting poor values with aggressive therapeutic interventions alters the course of brain ischemia and leads to better outcomes, or whether low $\mathrm{P}_{\mathrm{btO}_{2}}$ is simply a marker of higher disease severity.

\section{Targeting Brain Tissue Oxygenation}

The general strategy for correction of hypoxic $\mathrm{P}_{\mathrm{btO}}$ relies on correcting the underlying cause. Patients with low $\mathrm{P}_{\mathrm{btO}_{2}}$ values as a result of global hypoxemia should receive interventions to correct hypoxemia. Airway recruitment, increased PEEP, and increased $\mathrm{F}_{\mathrm{IO}_{2}}$ can be effective, depending on the etiology of hypoxemia, but these interventions are potentially associated with increased incidence of ventilator-induced lung injury, ${ }^{33}$ and should be used only to correct hypoxemia, generally irrespective of the $\mathrm{P}_{\mathrm{btO}_{2}}$ value.

Medical interventions to improve $\mathrm{P}_{\mathrm{btO}_{2}}$ in the absence of hypoxemia are parallel to those used to reduce ICP. The threshold for treatment of brain tissue hypoxia varies between institutions, but generally treatment becomes indicated for $\mathrm{P}_{\mathrm{btO}_{2}}$ values $<20 \mathrm{~mm} \mathrm{Hg}$. A tiered approach with escalating aggressive therapy is usually implemented. Initial relatively benign interventions include adjustment of the head of bed to above $30^{\circ}, 34,35$ and temperature management to below $37.5^{\circ} \mathrm{C} .{ }^{36}$

Prior to initiating more invasive treatment, the first reaction to brain tissue hypoxia is to perform a brief $\mathrm{F}_{\mathrm{IO}_{2}} 1.0$ challenge to assess the reliability of the $\mathrm{P}_{\mathrm{btO}_{2}}$ values. ${ }^{21}$ $\mathrm{P}_{\mathrm{btO}_{2}}$ should rise in tandem with the $\mathrm{P}_{\mathrm{aO}_{2}}$. The therapeutic benefit of hyperoxia is disputed, however. In theory, any benefit of increasing the dissolved oxygen is marginal, since dissolved oxygen is only 2-3\% of blood oxygen content, at maximum. However, some data do suggest a metabolic benefit to hyperoxic therapy to treat low $\mathrm{P}_{\mathrm{btO}_{2}}$. Recent work has shown that, after an $\mathrm{F}_{\mathrm{IO}_{2}}$ challenge, brain lactate and glutamate, measured by a microdialysis catheter, decreased, and glucose increased, at comparable levels of cerebral perfusion. ${ }^{37}$ It should be noted that these observations were obtained in patients with progressing injuries, without steady state baseline measurements, and receiving concomitant treatments. While brain metabolic biomarkers appeared to be improved, 3- and 6-month outcomes were not different. Similar work was previously published suggesting a reduction in lactate production in a cohort treated with increased $\mathrm{F}_{\mathrm{IO}}$; however, baseline measures were unstable, making it difficult to interpret the effect attributable to the intervention above and beyond the natural course of the brain metabolic biomarkers. ${ }^{38}$

Interestingly, observational studies have shown poor correlation between elevated ICP and $\mathrm{P}_{\mathrm{btO}}$, as well as lack of correlation with $\mathrm{P}_{\mathrm{aCO}}$ and hemoglobin level. ${ }^{39}$ However, transfusion of packed red blood cells to a target hemoglobin of $\geq 10 \mathrm{~g} / \mathrm{dL}$ may be more effective to increase the oxygen-carrying capacity of blood, ${ }^{40}$ than increasing $\mathrm{F}_{\mathrm{IO}_{2}}$. Likewise, cerebral ischemia may occur in the presence of normal ICP, due to multiple intervening mechanisms not captured by global measurements such as microvascular abnormalities, impaired autoregulation, or localized edema. Taken together, these observations suggest that, rather than relying on the absolute $\mathrm{P}_{\mathrm{btO}_{2}}$ numbers, trending the change in $\mathrm{P}_{\mathrm{btO}_{2}}$ values over time might be a more valuable tool to evaluate the response to therapy.

Patients with concomitant intracranial hypertension generally receive interventions primarily directed at raising cerebral perfusion pressure, either via increasing mean arterial pressure or decreasing ICP. ${ }^{11,41}$ Aggressive treatments to improve cerebral perfusion pressure are not without consequence, ${ }^{42}$ and many of the same treatments are indicated for the management of brain tissue hypoxia. The use of vasopressors to raise cerebral perfusion pressure is a risk factor for pulmonary complications, ${ }^{9}$ which in turn have been associated with worse neurological outcome following TBI. ${ }^{8}$ The use of heavy sedation or induced coma to decrease ICP could also result in increased duration of mechanical ventilation and length of hospital stay. ${ }^{43}$

\section{Outcome of Management Guided by Brain Tissue Oxygenation}

Several observational studies have been published comparing $\mathrm{P}_{\mathrm{btO}_{2}}$-guided management with ICP-guided management alone, and are summarized in the Table. ${ }^{10,44-49}$

Meixensberger et $\mathrm{al}^{44}$ first observed that, while $\mathrm{P}_{\mathrm{btO}_{2}}{ }^{-}$ guided management of cerebral perfusion was associated with relatively fewer episodes of cerebral hypoxia, there 


\section{Targeting Brain Tissue Oxygenation in Traumatic Brain Injury}

Table. Characteristics of Studies Comparing Outcomes of Patients Monitored With Intracranial Pressure Alone or Intracranial Pressure and Partial Brain Tissue Oxygen Pressure

\begin{tabular}{|c|c|c|c|c|c|c|c|c|c|}
\hline First Author & Group & $n$ & $\begin{array}{l}\mathrm{P}_{\mathrm{btO}_{2}} \\
\text { Treatment } \\
\text { Threshold } \\
(\mathrm{mm} \mathrm{Hg})\end{array}$ & $\begin{array}{l}\text { Control } \\
\text { Group }\end{array}$ & End Points & $\begin{array}{l}\text { Admission } \\
\text { Glasgow } \\
\text { Coma Score }\end{array}$ & $\begin{array}{l}\text { Injury } \\
\text { Severity } \\
\text { Score }\end{array}$ & $\begin{array}{l}\text { Outcome } \\
(\%)\end{array}$ & $\begin{array}{l}\text { Mortality } \\
\quad(\%)\end{array}$ \\
\hline \multirow[t]{2}{*}{ Meixensberger $^{44}$} & ICP & 40 & & Historical & $\begin{array}{l}\text { Glasgow outcome score } \\
\text { Good outcome }\end{array}$ & $6(4-7)$ & NR & $54 *$ & NR \\
\hline & $\mathrm{P}_{\mathrm{btO}_{2}}$ & 53 & $<10$ & & & $6(4-7)$ & NR & $65^{*}$ & NR \\
\hline \multirow[t]{2}{*}{ Steifel $^{45}$} & ICP & 25 & & Historical $\dagger$ & $\begin{array}{l}\text { Discharge } \\
\text { Rehabilitation facility/home versus } \\
\text { skilled nursing facility }\end{array}$ & $<8$ & $26(17-45)$ & $83 *$ & 44 \\
\hline & $\mathrm{P}_{\mathrm{btO}_{2}}$ & 28 & $<25$ & & & $<8$ & $27(17-50)$ & $100 *$ & $25 \ddagger$ \\
\hline \multirow[t]{2}{*}{ Adamides ${ }^{46}$} & $\mathrm{ICP}$ & 18 & & Concurrent & Mean Glasgow outcome score & $5.8 \pm 0.5$ & $34 \pm 3$ & $2.6 \S$ & 44 \\
\hline & $\mathrm{P}_{\mathrm{btO}_{2}}$ & 18 & $<15$ & & & $6.0 \pm 0.7$ & $33 \pm 3$ & $3.4 \S$ & 22 \\
\hline \multirow[t]{2}{*}{ Martini ${ }^{10}$} & $\mathrm{ICP}$ & 506 & & Concurrent & $\begin{array}{l}\text { Mean Functional Independence } \\
\text { Score }\end{array}$ & $5.6 \pm 2.3$ & $35 \pm 13$ & $8.6 \pm 3 \S$ & 23 \\
\hline & $\mathrm{P}_{\mathrm{btO}_{2}}$ & 123 & $<20$ & & & $5.1 \pm 2.2 \ddagger$ & $40 \pm 13 \ddagger$ & $7.6 \pm 3 \ddagger \S$ & 29 \\
\hline \multirow[t]{2}{*}{ McCarthy ${ }^{47}$} & $\mathrm{ICP}$ & 64 & & Historical & $\begin{array}{l}\text { Glasgow outcome score } \\
\text { Good outcome }\end{array}$ & $4.6 \pm 2.1$ & $26 \pm 8$ & $61^{*}$ & 36 \\
\hline & $\mathrm{P}_{\mathrm{btO}_{2}}$ & 81 & $<20$ & & & $4.0 \pm 1.8$ & $27 \pm 10$ & $79 *$ & 31 \\
\hline \multirow[t]{2}{*}{ Narotam $^{48}$} & $\mathrm{ICP}$ & 41 & & Historical & Mean Glasgow outcome score & $7.3 \pm 4.8$ & $27 \pm 9$ & $2.7 \pm 1.7 \S$ & 42 \\
\hline & $\mathrm{P}_{\mathrm{btO}_{2}}$ & 139 & $<20$ & & & $5.9 \pm 3.7 \ddagger$ & $32 \pm 13 \neq$ & $3.6 \pm 1.8 \ddagger \S$ & 26 \\
\hline \multirow[t]{2}{*}{ Spiotta $^{49}$} & ICP & 53 & & Historical & $\begin{array}{l}\text { Glasgow outcome score } \\
\text { Good outcome }\end{array}$ & $\begin{array}{c}\text { GCS: } 3 \\
77 \%\end{array}$ & $35 \pm 14$ & $40^{*}$ & 45 \\
\hline & $\mathrm{P}_{\mathrm{btO}_{2}}$ & 70 & $<20$ & & & $\begin{array}{l}\text { GCS: } 3 \\
67 \%\end{array}$ & $35 \pm 12$ & $64 *$ & 26 \\
\hline \multicolumn{10}{|c|}{$\begin{array}{l}\text { * Represents percentage of patients whose outcome was scored as "good." } \\
\dagger \text { Controls matched to cases for Glasgow Coma Score (GCS). } \\
\text { † Significant compared to control group. } \\
\S \text { Mean outcome score. } \\
\mathrm{P}_{\mathrm{btO}_{2}}=\text { partial pressure of brain tissue oxygen } \\
\mathrm{ICP}=\text { intracranial pressure } \\
\mathrm{NR}=\text { not reported }\end{array}$} \\
\hline
\end{tabular}

was no difference in neurological outcome at 6 months, using the Glasgow Outcome Scale, which is a 5-level scale in which 1 is death, 2 is a vegetative state, 3 is severe disability, 4 is moderate disability, and 5 is good functional recovery. ${ }^{50} \mathrm{~A}$ much improved version, the Glasgow Outcome Scale-Extended, is now available. ${ }^{51}$ Meixensberger et $\mathrm{al}^{44}$ used a historical group as controls, and the patients in the control group had $\mathrm{P}_{\mathrm{btO}}$ monitors in place that were not used to guide management. Interestingly, in both groups, there was a U-shaped distribution of episodes of brain tissue hypoxia: in the first day after injury, and peaking again on days 7-10. The early episodes of brain tissue hypoxia appeared to be less modifiable by $\mathrm{P}_{\mathrm{btO}_{2}}{ }^{-}$ guided therapy whereas later episodes of hypoxia were relatively more common in the group without $\mathrm{P}_{\mathrm{btO}_{2}}$-guided management. Perhaps this suggests that there are multiple mechanisms underlying brain tissue hypoxia and those that occur early after injury are less modifiable but more highly predictive of outcome. The outcomes measured were not adjusted for potential confounders, and it is unknown if the results would have been different after accounting for differences in patient characteristics. ${ }^{44}$

In a prospective, observational study, Narotam et $\mathrm{al}^{48}$ compared an ICP-guided protocol with one supplemented with $\mathrm{P}_{\mathrm{btO}_{2}}$ monitoring in 139 patients with TBI and major trauma. The investigators found that patients monitored with both ICP and $\mathrm{P}_{\mathrm{btO}_{2}}$ monitoring had almost twice the odds of a good neurological outcome, as defined by 6-month Glasgow Outcome Scale scores. They also observed a roughly $15 \%$ absolute reduction in mortality, when compared to historical controls. The patients with $\mathrm{P}_{\mathrm{btO}_{2}}$ monitoring had significantly worse admission Glasgow Coma Scale scores, and worse injury severity scores, but other differences between the groups, such as the mechanism of injury and the intracranial pathology, were not compared between the groups. Also, the outcome measures were not adjusted to take into account differences in confounding factors, though these would likely favor an additional benefit for $\mathrm{P}_{\mathrm{btO}_{2}}$ monitoring, as this group had worse prognosis at admission. This study does confirm that brain tissue 


\section{Targeting Brain Tissue Oxygenation in Traumatic Brain Injury}

hypoxia is associated with increased odds of death and poor functional outcome, especially when $\mathrm{P}_{\mathrm{btO}}$ is low in association with refractory elevated ICP over a long period of time. 48

McCarthy et $\mathrm{al}^{47}$ compared 48 patients with ICP monitoring to 63 patients with multimodal $\mathrm{P}_{\mathrm{btO}_{2}}$ monitoring, and found a $70 \%$ increase in the odds of a good neurological outcome at 3 months with multimodal monitoring. Spiotta et $\mathrm{al}^{49}$ compared similar numbers of patients, and reported a nearly 3 -fold increase in the odds of a favorable outcome in patients with multimodal monitoring, as well as significantly improved mortality.

One recent meta-analysis pooled the results of these studies ${ }^{10,45-48}$ and found that $\mathrm{P}_{\mathrm{btO}_{2}}$-guided management nearly doubled the odds of a favorable neurological outcome. ${ }^{52}$ All of the included studies were retrospective, utilized historical controls, and measured outcome based on the Glasgow Outcome Scale. Three studies were not included in the meta-analysis by Nangunoori et al, ${ }^{52}$ due to the lack of reporting of the Glasgow Outcome Scale data.

Adamides et $\mathrm{al}^{46}$ conducted a small, retrospective analysis of $\mathrm{P}_{\mathrm{btO}_{2}}$-guided management compared to both historical and concurrent controls. The authors noted trends toward better outcome and improved mortality in patients with $\mathrm{P}_{\mathrm{btO}_{2}}$-guided management, but the number of patients included in the study was very small, and none of their differences in outcome measures were statistically significant.

In a study of 53 patients, Stiefel et a ${ }^{45}$ observed that patients who received $\mathrm{P}_{\mathrm{btO}}$-guided interventions had decreased mortality (25\% vs $44 \%$ ), when compared to historical, case-matched controls monitored with ICP only. Data regarding Glasgow Coma Scale scores at admission are not detailed, but the authors report that the entire population had an admission Glasgow Coma Scale $<8$. They also did not specifically measure outcomes other than mortality, but report that $100 \%$ of patients who received $\mathrm{P}_{\mathrm{btO}_{2}}$ monitoring were discharged to home or rehabilitation centers, compared to $87 \%$ of patients with ICP monitoring. ${ }^{45}$

Only one study has shown no benefit to $\mathrm{P}_{\mathrm{btO}_{2}}$-guided therapy for patients with severe TBI, and was conducted by the authors of this review. ${ }^{10}$ While we demonstrated differences in the ICU course of patients with brain tissue oxygen monitoring, most notably increased resource utilization, longer mechanical ventilation, and increased costs, we did not find a reduction in hospital mortality or functional outcome in patients with severe TBI who were managed with $\mathrm{P}_{\mathrm{btO}_{2}}$ monitoring. We reported a mortality of $29 \%$ in patients with multimodal monitoring, compared with $23 \%$ for ICP monitoring alone, and significantly worse functional outcome in patients with $\mathrm{P}_{\mathrm{btO}_{2}}$ monitoring.

The major limitation of this study was the utilization of a concurrent control group. The $\mathrm{P}_{\mathrm{btO}_{2}}$-monitored patients were selected at the discretion of the admitting neurosur- geon, without specific guidelines for insertion, which resulted in the group of patients receiving $\mathrm{P}_{\mathrm{btO}_{2}}$ monitoring having significantly worse neurologic injury at presentation, and a worse prognosis. While statistical adjustments were made for the imbalances in baseline characteristics predictive of prognosis, it is likely that residual confounding was present. What we did emphasize, however, is that many more of the patients in the $\mathrm{P}_{\mathrm{btO}_{2}}$ group received therapeutic interventions to manage hypoxic $\mathrm{P}_{\mathrm{btO}}$ values, each with possible adverse systemic consequences, and at significantly increased institutional cost, without a clear benefit on outcome..$^{10}$

An important issue with several of the studies described above is the utilization of historical controls. Steifel et al ${ }^{45}$ and Narotam et $\mathrm{al}^{48}$ report mortality of $44 \%$ and $42 \%$, respectively, in the group receiving ICP monitoring alone, which is on average high, when compared to other United States trauma centers, irrespective to the monitoring modality used. Only the mortality of their $\mathrm{P}_{\mathrm{btO}_{2}}$-monitored group (25\% and $26 \%$, respectively) were similar to that seen in TBI patients in United States trauma centers in general. ${ }^{1,53}$ This suggests that differences in mortality could have been the result of temporal trends rather than the actual effect of therapies used. The treatment protocols employed by each study to treat low $\mathrm{P}_{\mathrm{btO}_{2}}$ were also varied, making it difficult to ascertain which components of $\mathrm{P}_{\mathrm{btO}_{2}}$-guided therapy, if any, were beneficial. Given these limitations, the need for further study of $\mathrm{P}_{\mathrm{btO}_{2}}$-guided management is clear.

An ongoing phase II multicenter trial is currently recruiting TBI patients, with an enrollment goal of 132 subjects. Patients are randomized to ICP-guided monitoring or ICP- and $\mathrm{P}_{\mathrm{btO}_{2}}$-guided monitoring, using a tiered approach to escalate therapy. The results of this trial will provide important data to reconcile the findings of the observational studies and likely preliminary estimates for the planning of a larger phase III trial.

\section{Summary}

The avoidance of secondary injury to the brain following TBI is an important focus of neurocritical care. Brain tissue hypoxia measured by a direct intraparenchymal electrode is associated with poor vital and neurological outcome. While $\mathrm{P}_{\mathrm{btO}}$ is a modifiable variable in the postinjury period, and although there is a suggestion of improved outcomes among patients managed with $\mathrm{P}_{\mathrm{btO}_{2}}$-guided therapy, whether or not this translates into an improvement in clinical outcomes overall remains to be confirmed. The observational studies on targeting brain tissue oxygenation are difficult to compare, especially given the variation of the treatment protocols used, as these are the true modifiers of outcome. At present it is reasonable to consider the $\mathrm{P}_{\mathrm{btO}_{2}}$ monitor as a valuable tool to evaluate the response to 


\section{Targeting Brain Tissue Oxygenation in Traumatic Brain Injury}

brain resuscitation interventions; however, implementing therapies to target a specific $\mathrm{P}_{\mathrm{btO}}$, value seems premature, based on the available literature. A randomized trial is needed to evaluate the efficacy of a brain tissue hypoxia directed management protocol, and until then wide utilization of $\mathrm{P}_{\mathrm{btO}_{2}}$ monitoring-based therapy cannot be recommended.

\section{REFERENCES}

1. Thurman DJ, Alverson C, Dunn KA, Guerrero J, Sniezek JE. Traumatic brain injury in the United States: a public health perspective. J Head Trauma Rehabil 1999;14(6):602-615.

2. Chesnut RM, Marshall LF, Klauber MR, Blunt BA, Baldwin N, Eisenberg HM, et al. The role of secondary brain injury in determining outcome from severe head injury. J Trauma 1993;34(2): 216-222.

3. Dreier JP. The role of spreading depression, spreading depolarization and spreading ischemia in neurological disease. Nat Med 2011;17(4): 439-447.

4. Hartings JA, Bullock MR, Okonkwo DO, Murray LS, Murray GD, Fabricius M, et al. Spreading depolarisations and outcome after traumatic brain injury: a prospective observational study. Lancet Neurol 2011;10(12):1058-1064.

5. Miller JD, Becker DP. Secondary insults to the injured brain. J R Coll Surg Edinb 1982;27(5):292-298.

6. Rogers FB, Shackford SR, Trevisani GT, Davis JW, Mackersie RC, Hoyt DB. Neurogenic pulmonary edema in fatal and nonfatal head injuries. J Trauma 1995;39(5):860-866, discussion 866-868.

7. Mascia L, Zavala E, Bosma K, Pasero D, Decaroli D, Andrews P, et al. High tidal volume is associated with the development of acute lung injury after severe brain injury: an international observational study. Crit Care Med 2007;35(8):1815-1820.

8. Bratton SL, Davis RL. Acute lung injury in isolated traumatic brain injury. Neurosurg 1997;40(4):707-712.

9. Contant CF, Valadka AB, Gopinath SP, Hannay HJ, Robertson CS. Adult respiratory distress syndrome: a complication of induced hypertension after severe head injury. J Neurosurg 2001;95(4):560-568.

10. Martini RP, Deem S, Yanez ND, Chesnut RM, Weiss NS, Daniel S, et al. Management guided by brain tissue oxygen monitoring and outcome following severe traumatic brain injury. J Neurosurg 2009; 111(4):644-649.

11. Brain Trauma Foundation; American Association of Neurological Surgeons; Congress of Neurological Surgeons; Joint Section on Neurotrauma and Critical Care; AANS/CNS; Bratton SL, Chestnut RM, Ghajar J, McConnell Hammond FF, Harris OA, Hartl R, et al. Guidelines for the management of severe traumatic brain injury. VI. Indications for intracranial pressure monitoring. J Neurotrauma 2007; 24(Suppl 1):S37-S44. Erratum in: J Neurotrauma 2008;25(3):276-278.

12. Narayan RK, Kishore PR, Becker DP, Ward JD, Enas GG, Greenberg RP, et al. Intracranial pressure: to monitor or not to monitor? A review of our experience with severe head injury. J Neurosurg 1982; 56(5):650-659.

13. Marmarou A, Anderson RL, Ward JD. Impact of ICP instability and hypotension on outcome in patients with severe head trauma. J Neurosurg 1991;75(S59-S66).

14. Narayan RK, Greenberg RP, Miller JD, Enas GG, Choi SC, Kishore $\mathrm{PR}$, et al. Improved confidence of outcome prediction in severe head injury. A comparative analysis of the clinical examination, multimodality evoked potentials, CT scanning, and intracranial pressure. J Neurosurg 1981;54(6):751-762.
15. Gopinath SP, Robertson CS, Contant CF, Hayes C, Feldman Z, Narayan RK, et al. Jugular venous desaturation and outcome after head injury. J Neurol Neurosurg Psychiatry 1994;57(6):717-723.

16. Servadei F, Antonelli V, Giuliani G, Fainardi E, Chieregato A, Targa L. Evolving lesions in traumatic subarachnoid hemorrhage: prospective study of 110 patients with emphasis on the role of ICP monitoring. Acta Neurochir Suppl 2002;81(Suppl):81-82.

17. Le Roux PD, Newell DW, Lam AM, Grady MS, Winn HR. Cerebral arteriovenous oxygen difference: a predictor of cerebral infarction and outcome in patients with severe head injury. J Neurosurg 1997; 87(1):1-8

18. Brain Trauma Foundation; American Association of Neurological Surgeons; Congress of Neurological Surgeons; Joint Section on Neurotrauma and Critical Care; Bratton SL, Chestnut RM, Ghajar J, McConnell Hammond FF, Harris OA, Hartl R, et al. Guidelines for the management of severe traumatic brain injury. X. Brain oxygen monitoring and thresholds. J Neurotrauma 2007;24(Suppl 1):S65S70. Erratum in: J Neurotrauma 2008;25(3):276-278.

19. Lang EW, Mulvey JM, Mudaliar Y, Dorsch NW. Direct cerebral oxygenation monitoring: a systematic review of recent publications. Neurosurg Rev 2007;30(2):99-106, discussion 106-107.

20. Rosenthal G, Hemphill JC 3rd, Sorani M, Martin C, Morabito D, Obrist WD, et al. Brain tissue oxygen tension is more indicative of oxygen diffusion than oxygen delivery and metabolism in patients with traumatic brain injury. Crit Care Med 2008;36(6):1917-1924.

21. Gupta AK, Hutchinson PJ, Fryer T, Al-Rawi PG, Parry DA, Minhas PS, et al. Measurement of brain tissue oxygenation performed using positron emission tomography scanning to validate a novel monitoring method. J Neurosurg 2002;96(2):263-268.

22. Menon DK, Coles JP, Gupta AK, Fryer TD, Smielewski P, Chatfield DA, et al. Diffusion limited oxygen delivery following head injury. Crit Care Med 2004;32(6):1384-1390.

23. Niatsetskaya ZV, Sosunov SA, Matsiukevich D, Utkina-Sosunova IV, Ratner VI, Starkov AA, et al. The oxygen free radicals originating from mitochondrial complex I contribute to oxidative brain injury following hypoxia-ischemia in neonatal mice. J Neurosci 2012; 32(9):3235-3244.

24. Hoffman WE, Charbel FT, Portillo GG, Edelman G, Ausman JI. Regional tissue $\mathrm{P}_{\mathrm{O}_{2}}, \mathrm{P}_{\mathrm{CO}_{2}}, \mathrm{pH}$ and temperature measurement. Neurol Res 1998;20(Suppl 1):S81-S84.

25. Carmona Suazo JA, Maas AI, van den Brink WA, van Santbrink H, Steyerberg EW, Avezaat CJ. $\mathrm{CO}_{2}$ reactivity and brain oxygen pressure monitoring in severe head injury. Crit Care Med 2000;28(9): 3268-3274.

26. Diringer MN, Aiyagari V, Zazulia AR, Videen TO, Powers WJ. Effect of hyperoxia on cerebral metabolic rate for oxygen measured using positron emission tomography in patients with acute severe head injury. J Neurosurg 2007;106(4):526-529.

27. Dings J, Meixensberger J, Jager A, Roosen K. Clinical experience with 118 brain tissue oxygen partial pressure catheter probes. Neurosurgery 1998;43(5):1082-1095.

28. van den Brink WA, van Santbrink H, Steyerberg EW, Avezaat CJ, Suazo JA, Hogesteeger C, et al. Brain oxygen tension in severe head injury. Neurosurgery 2000;46(4):868-876, discussion 876-878.

29. Maas AI, Fleckenstein W, de Jong DA, van Santbrink H. Monitoring cerebral oxygenation: experimental studies and preliminary clinical results of continuous monitoring of cerebrospinal fluid and brain tissue oxygen tension. Acta Neurochir Suppl (Wien) 1993;59:50-57.

30. Valadka AB, Gopinath SP, Contant CF, Uzura M, Robertson CS. Relationship of brain tissue $\mathrm{P}_{\mathrm{O}_{2}}$ to outcome after severe head injury. Crit Care Med 1998;26(9):1576-1581.

31. Bardt TF, Unterberg AW, Hartl R, Kiening KL, Schneider GH, Lanksch WR. Monitoring of brain tissue $\mathrm{P}_{\mathrm{O}_{2}}$ in traumatic brain in- 


\section{Targeting Brain Tissue Oxygenation in Traumatic Brain Injury}

jury: effect of cerebral hypoxia on outcome. Acta Neurochir Suppl 1998;71(Suppl):153-156.

32. Maloney-Wilensky E, Gracias V, Itkin A, Hoffman K, Bloom S, Yang W, et al. Brain tissue oxygen and outcome after severe traumatic brain injury: a systematic review. Crit Care Med 2009;37(6): 2057-2063.

33. Dreyfuss D, Saumon G. Ventilator-induced lung injury: lessons from experimental studies. Am J Respir Crit Care Med 1998;157(1):294323.

34. Ng I, Lim J, Wong HB. Effects of head posture on cerebral hemodynamics: its influences on intracranial pressure, cerebral perfusion pressure, and cerebral oxygenation. Neurosurg 2004;54(3):593-597, discussion 598.

35. Meixensberger J, Baunach S, Amschler J, Dings J, Roosen K. Influence of body position on tissue- $\mathrm{P}_{\mathrm{O}_{2}}$, cerebral perfusion pressure and intracranial pressure in patients with acute brain injury. Neurol Res 1997;19(3):249-253.

36. Puccio AM, Fischer MR, Jankowitz BT, Yonas H, Darby JM, Okonkwo DO. Induced normothermia attenuates intracranial hypertension and reduces fever burden after severe traumatic brain injury. Neurocrit Care 2009;11(1):82-87.

37. Tolias CM, Reinert M, Seiler R, Gilman C, Scharf A, Bullock MR. Normobaric hyperoxia-induced improvement in cerebral metabolism and reduction in intracranial pressure in patients with severe head injury: a prospective historical cohort-matched study. J Neurosurg 2004;101(3):435-444

38. Menzel M, Doppenberg EM, Zauner A, Soukup J, Reinert MM, Bullock R. Increased inspired oxygen concentration as a factor in improved brain tissue oxygenation and tissue lactate levels after severe human head injury. J Neurosurg 1999;91(1):1-10.

39. Chang JJ, Youn TS, Benson D, Mattick H, Andrade N, Harper CR, et al. Physiologic and functional outcome correlates of brain tissue hypoxia in traumatic brain injury. Crit Care Med 2009;37(1):283-290.

40. Smith MJ, Stiefel MF, Magge S, Frangos S, Bloom S, Gracias V, et al. Packed red blood cell transfusion increases local cerebral oxygenation. Crit Care Med 2005;33(5):1104-1108

41. Johnston AJ, Steiner LA, Coles JP, Chatfield DA, Fryer TD, Smielewski P, et al. Effect of cerebral perfusion pressure augmentation on regional oxygenation and metabolism after head injury. Crit Care Med 2005;33(1):189-195, discussion 255-257.

42. Robertson CS, Valadka AB, Hannay HJ, Contant CF, Gopinath SP, Cormio M, et al. Prevention of secondary ischemic insults after severe head injury. Crit Care Med 1999;27(10):2086-2095.
43. Girard TD, Kress JP, Fuchs BD, Thomason JW, Schweickert WD, Pun BT, et al. Efficacy and safety of a paired sedation and ventilator weaning protocol for mechanically ventilated patients in intensive care (Awakening and Breathing Controlled trial): a randomised controlled trial. Lancet 2008;371(9607):126-134.

44. Meixensberger J, Jaeger M, Vath A, Dings J, Kunze E, Roosen K. Brain tissue oxygen guided treatment supplementing ICP/CPP therapy after traumatic brain injury. J Neurol Neurosurg Psychiatry 2003; 74(6):760-764.

45. Stiefel MF, Spiotta A, Gracias VH, Garuffe AM, Guillamondegui O, Maloney-Wilensky E, et al. Reduced mortality rate in patients with severe traumatic brain injury treated with brain tissue oxygen monitoring. J Neurosurg 2005;103(5):805-811.

46. Adamides AA, Cooper DJ, Rosenfeldt FL, Bailey MJ, Pratt N, Tippett N, et al. Focal cerebral oxygenation and neurological outcome with or without brain tissue oxygen-guided therapy in patients with traumatic brain injury. Acta Neurochir 2009;151(11):1399-1409.

47. McCarthy MC, Moncrief H, Sands JM, Markert RJ, Hall LC, Wenker IC, et al. Neurologic outcomes with cerebral oxygen monitoring in traumatic brain injury. Surgery 2009;146(4):585-590, discussion 590-591.

48. Narotam PK, Morrison JF, Nathoo N. Brain tissue oxygen monitoring in traumatic brain injury and major trauma: outcome analysis of a brain tissue oxygen-directed therapy. J Neurosurg 2009;111(4): 672-682.

49. Spiotta AM, Stiefel MF, Gracias VH, Garuffe AM, Kofke WA, Maloney-Wilensky E, et al. Brain tissue oxygen-directed management and outcome in patients with severe traumatic brain injury. J Neurosurg 2010;113(3):571-580.

50. Jennett B, Bond M. Assessment of outcome after severe brain damage. Lancet 1975;1(7905):480-484.

51. Wilson JT, Pettigrew LE, Teasdale GM. Structured interviews for the Glasgow Outcome Scale and the extended Glasgow Outcome Scale: guidelines for their use. J Neurotrauma 1998;15(8):573-585.

52. Nangunoori R, Maloney-Wilensky E, Stiefel M, Park S, Andrew Kofke W, Levine JM, et al. Brain tissue oxygen-based therapy and outcome after severe traumatic brain injury: a systematic literature review. Neurocrit Care 2012;17(1):131-138.

53. Bulger EM, Nathens AB, Rivara FP, Moore M, MacKenzie EJ, Jurkovich GJ. Management of severe head injury: institutional variations in care and effect on outcome. Crit Care Med 2002;30(8): 1870-1876.

\section{Discussion}

Kevin Ward: Do you currently do microdialysis at the same time?

Treggiari: No, we don't use this technology in clinical practice.

Kevin Ward: I ask because I'm curious about the data you showed on lactate and glucose but not pyruvate. You would really need lactate and pyruvate to understand the redox reaction, because the brain can use lactate as a fuel, so you never know if it's coming or going. Are there plans to look at the microdiasylate for these entities?

Treggiari: Our neurosurgeons have been considering this for several years, but outside the investigational interest there are no established clinical guidelines or convincing data supporting improved outcomes with this monitoring modality, so we are not using it in clinical practice.

MacIntyre: I deal with patients who do not have neurological issues such as ICP problems or TBI. But I do have people who are very hypoxemic and are on lots and lots of respiratory support: high $\mathrm{F}_{\mathrm{IO}_{2}}$ and high ventilator pressures. I raise the possibility of maybe using this kind of technology in non-braininjured patients to guide things like ventilator therapy. Kevin raised the point that maybe splanchnic monitoring may be better. Are there studies on this kind of technology in non-brain injured patients?

Treggiari: To my knowledge there are no studies of monitoring brain oxygenation in the absence of any detectable brain injury. That could be an interesting research area. I would 
expect that, as long as the brain has normal auto-regulation, it would be unlikely to observe responses outside those predicable based on neurophysiology. In older literature there was concern about adverse neurological outcomes in patients rapidly exposed to permissive hypercapnia. To my knowledge there is not a clear attributable effect of hypoxemia or hypercapnia per se on neurocognitive function. It's certainly a possibility, but it's difficult to tease out, due to the multitude of factors intervening during critical illness.

Kallet: I was interested but not quite sure I followed the part about brain metabolism. I got the impression from that study ${ }^{1}$ that the patients weren't really stable at baseline-there was some question about that. Is that true?

Treggiari: Correct: the baseline was not steady, at least in the representative patient represented in that figure.

Kallet: Secondly, the lactate was normal and went down, so you'd assume the metabolism had dropped. Did the glucose go up?

Treggiari: The glucose stayed the same and didn't increase, so it is difficult to interpret those data.

Kallet: What I'm driving at relates to what is known about the effects of hyperoxia in the lungs. Cells with higher metabolic rates appear to be particularly vulnerable to $\mathrm{O}_{2}$ toxicity. For instance, the pulmonary capillary endothelium is the primary site of hyperoxia-induced lung injury. Andrea Harabin did a study of hyperoxia years ago, showing that, over the course of 4 days, pulmonary endothelial damage caused cellular metabolism to drop by $50 \% .^{2}$ So it wouldn't strike me as extraordinary that even a few hours of hyperoxia in the brain might interfere with metabolism. Because hyperoxia interferes with enzymes-maybe not to a toxic level where necrosis or ap- optosis would be evident, but it seems reasonable that several hours of hyperoxia could disrupt normal enzymes function.

Treggiari: One of the therapeutic goals is to shift brain metabolism from anaerobic to aerobic metabolism. In the study of induced hyperoxemia it is unclear if hyperoxemia affords an increase in aerobic metabolism versus a shift or reduction in metabolic activity.

Kallet: I don't think the interest in neurotrauma and neurologic research has been on the effects of hyperoxia. I think most of the concern is hypoxemia, so I'm not sure there are any animal data on hyperoxia and brain injury.

Treggiari: Some experimental data suggest that hyperoxia could be deleterious during reperfusion injury in the ischemic brain. ${ }^{3}$ Hyperoxia could increase the availability of free oxygen radicals and increase oxidative stress, which we would try to avoid.

Criner: How much is known about regional $\mathrm{P}_{\mathrm{btO}_{2}}$ variation in the normal brain?

Treggiari: We actually know more about the abnormal brain. There is a lot of variability in the contused, damaged brain, but I am not aware of data on physiologic variations in the normal brain, except for the validation of normal values. In patients with brain injury intensively monitored with $2 \mathrm{P}_{\mathrm{btO}_{2}}$ probes on each side, we frequently observe that the values are substantially different.

Criner: Do you think that regional variation may contribute to the lack of association?

Treggiari: It could be due to regional variation, but it could also be just technical malfunction or an issue of positioning. These are limitations related to what measurement the monitoring device is really capturing.

Criner: For the study you did, do you have any sense as to how different the $\mathrm{P}_{\mathrm{btO}_{2}}$ was in the patient you were monitoring for systemic manifestations of improved outcomes like systemic $\mathrm{O}_{2}$ transport or global $\mathrm{O}_{2}$, as opposed to regional?

Treggiari: Yes, we have a relatively good idea. These are, in general, young and otherwise previously healthy patients with isolated traumatic brain injury, so overall we expect that the global $\mathrm{O}_{2}$ transport to be within normal physiologic values. This also means that, unlike patients with multiple trauma, there is less contribution to the inflammatory response other than the brain dysfunction.

Criner: In your study, could you see whether there was any association between an upper limit or the relationship between $\mathrm{P}_{\mathrm{btO}_{2}}$ and outcome, in the sense of whether it's a $\mathrm{U}$ shape relationship or a direct linear correlation?

Treggiari: That's an interesting point, and we have not looked at the shape of the relationship. However, in these patients we are actively treating the $\mathrm{P}_{\mathrm{btO}_{2}}$, and not just observing its natural course. The data would need to be interpreted in the context of someone who's actively trying to resuscitate these patients and normalize their $\mathrm{P}_{\mathrm{btO}_{2}}$ values.

Claure: Did you consider the changes in brain metabolism with hypothermia? And in the case of brain death, what readings would you obtain? Do you see any advantage to non-invasive near-infrared monitoring of the brain in neonates?

Treggiari: In adults the thickness of the skull makes it difficult for the energy to penetrate to sufficient depth, 
so the near-infrared technology is unreliable. In neonates, who have a thinner, less calcified skull, this technology might provide better and more reliable information. The question of brain death is interesting. A recent study in a pig model of brain death showed a drop in $\mathrm{P}_{\mathrm{btO}_{2}}$ below 10 with increasing intracranial volume, while the lactate/pyruvate ratio continued to increase. ${ }^{4}$

Pierson:* I applaud your caution and objectivity in evaluating this new technology-especially coming, as you do, from an institution where there is strong advocacy and involvement in its use. It emphasizes to me the distinction between how we develop and learn about technology in health care, as compared to the situation with pharmaceutical agents. For a new pharmaceutical agent, it gets developed, it then is rigorously studied, and only after a study in the population for whom it is intended does it then get licensed, introduced, and finally widely used. Technology, particularly in the critical care unit, gets developed with typically a strong theoretical rationale, and is then directly introduced into clinical practice and often very widely adopted and used, and only finally some time later does it get properly studied.

I' $m$ afraid I was reminded of the Swan-Ganz catheter as you were talking, as a technology with a compelling rationale that in the hands of the people advocating for it seemed to be great stuff. As you've pointed out, the device you're describing is just now entering that final phase of a randomized controlled trial, so we'll see how that turns out. But I think the history of critical care, which applies to a certain degree to $\mathrm{O}_{2}$ in all contexts, but especially in critical care, is of the in-

\footnotetext{
* David J Pierson MD FAARC, Emeritus, Division of Pulmonary and Critical Care Medicine, Harborview Medical Center, University of Washington, Seattle, Washington.
}

troduction of some exciting new thing, which quickly gets widely used, and only later gets studied, and many times found not to have the properties its advocates claimed.

Treggiari: I completely agree. The introduction of this monitoring device in clinical practice reminds me very much of the history of the pulmonary artery catheter. It's interesting that it's really about what we do with the information acquired from the monitor, and not just the monitoring itself. From the FDA's perspective, these devices are not "approved," they're "cleared" for use, which somehow has a less rigorous requirement for investigation than a product that requires approval.

Kevin Ward: One of the big issues for me (and perhaps for the readers), based on your overview, is not the concept of monitoring, but the concept that increasing your $\mathrm{F}_{\mathrm{IO}_{2}}$ to increase your $\mathrm{P}_{a O_{2}}$ is therapeutic at the tissue level. If we look at the whole equation for $\mathrm{O}_{2}$ delivery, we would say that getting your $\mathrm{P}_{\mathrm{O}_{2}}$ above $100 \mathrm{~mm} \mathrm{Hg}$ wouldn't really provide any extra oomph or fuel in terms of $\mathrm{O}_{2}$ for your tissue. One camp-which our neurosurgeons are definitely inbelieves that an increase in $\mathrm{F}_{\mathrm{IO}_{2}}$ is therapeutic for TBI: that's the Richmond camp. Others feel differently about this.

But I think what's really the intriguing thing is that this little bit of extra $\mathrm{P}_{\mathrm{O}_{2}}$ that can be delivered to the tissue by increasing $\mathrm{F}_{\mathrm{IO}_{2}}$ is therapeutic. The fact that you have the ability to monitor that could be gratifying, but the key is not whether or not the monitor makes a difference, but whether or not increasing the $\mathrm{P}_{\mathrm{O}_{2}}$ by $10 \mathrm{~mm} \mathrm{Hg}$ in the brain by dialing up the $\mathrm{F}_{\mathrm{IO}_{2}}$ can save brain cells.

Treggiari: I'm skeptical about that idea of increasing the $\mathrm{F}_{\mathrm{IO}_{2}}$. We allow this to happen for a short time, to evaluate the responsiveness of the mea- surements to changing conditions. Other than that, I believe that adjusting the $\mathrm{F}_{\mathrm{IO}_{2}}$ just to make the number look better does not provide a real benefit to the patient. As I said, the metabolic data are really not convincing, and it is uncertain that by delivering the extra $\mathrm{O}_{2}$ we are making a difference.

Branson: When this first came about at my institution, I would find patients with isolated head injury on APRV [airway pressure release ventilation] and $100 \% \mathrm{O}_{2}$. And there seemed to be competing interests for increasing the brain tissue $\mathrm{P}_{\mathrm{O}_{2}}$ and really tearing up the lungs with large tidal volumes and higher airway pressures. This $\mathrm{F}_{\mathrm{IO}_{2}}$ challenge is clearly different in the TBI patient with a pulmonary contusion and a liver injury than it is in a patient with an isolated blunt trauma to the head and no other injury. What do you think is the primary lung pathology in patients with isolated head injury? Why are they hypoxemic? We tend to treat it like it's ARDS, but sometimes I think it's just ventilationperfusion mismatch, often related to the perfusion, not the ventilation.

Treggiari: The criteria compatible with a diagnosis of neurogenic pulmonary edema are actually quite rarely met. We estimate it to be no more than $6 \%$. Neurogenic pulmonary edema is typically seen in patients with extensive and severe TBI: it is not characteristic of patients with mild brain injury. The mechanisms leading to neurogenic pulmonary edema are multifactorial, but there is evidence of an inflammatory process leading to endothelial injury and impaired capillary permeability. Therefore it's not a simple hydrostatic problem related to cardiac dysfunction leading to cardiogenic edema. Because it's an inflammatory process, it is unlikely to respond to diuretics. The fluid in the alveoli is albumin and protein rich, so the treatment approach should be similar to that for ARDS. 


\section{Targeting Brain Tissue Oxygenation in Traumatic Brain Injury}

Kallet: A paper in Critical Care Medicine described the incidence of ALI [acute lung injury] and ARDS in neurological illness, which was about a third of these patients. ${ }^{5}$ Basically they found that pneumonia was the leading cause of ALI, and it was associated with the loss of cough and gag reflex from impaired lower brain stem function. So a lot of these patients tend to have aspirated, and it's not usually picked up that they meet the ALI or ARDS criteria.

Treggiari: We published a study some years ago, with Gordon Rubenfeld, on the incremental mortality associated with developing ARDS in patients with trauma, including brain injury. ${ }^{6}$ After accounting for severity of injury and some other potential confounders, we did not observe attributable incremental mortality in these trauma patients.

Branson: I've been impressed that in some of these cases the neurosurgery guys will call me and tell me they're having trouble with increasing $\mathrm{P}_{\mathrm{aO}_{2}}$ - and I'm not advocating giving it to everybody, but $1-10 \mathrm{ppm}$ of inhaled nitric oxide in head injury patients will sometimes triple their $\mathrm{P}_{\mathrm{aO}_{2}}$. I think aerosolized prostacyclin might do the same thing. But the issue is that there seems to be something unique about that group of patients, that ventilationperfusion matching is different and can be modified by an inhaled vasodilator. Have you had that experience?

Treggiari: I haven't looked specifically at the response in TBI, but I did some work on how we can predict the response to inhaled nitric oxide in patients with ARDS. We did a study on cardiac function, and particularly the stretch of cardiac chambers, using ANP [atrial natriuretic peptide] and BNP [brain natriuretic peptide] as biomarkers, ${ }^{7}$ and the indexes of cardiac stretch, as measured by elevated BNP/ANP, were predictive of the response to inhaled nitric oxide. It is possible that TBI patients with acute myocardial dysfunction (neurogenic stunned myocardium), and maybe acute pulmonary hypertension, may respond better to inhaled nitric oxide. However, this is very speculative at this point.

1. Menzel M, Doppenberg EM, Zauner A, Soukup J, Reinert MM, Bullock R. In- creased inspired oxygen concentration as a factor in improved brain tissue oxygenation and tissue lactate levels after severe human head injury. J Neurosurg 1999;91(1):1-10.

2. Harabin AL, Homer LD, Bradley ME. Pulmonary oxygen toxicity in awake dogs: metabolic and physiological effects. J Appl Physiol 1984;57(5):1480-1488.

3. Niatsetskaya ZV, Sosunov SA, Matsiukevich D, Utkina-Sosunova IV, Ratner VI, Starkov AA, et al. The oxygen free radicals originating from mitochondrial complex I contribute to oxidative brain injury following hypoxia-ischemia in neonatal mice. J Neurosci 2012;32(9):3235-3244.

4. Purins K, Enblad P, Wiklund L, Lewén A. Brain tissue oxygenation and cerebral perfusion pressure thresholds of ischemia in a standardized pig brain death model. Neurocrit Care 2012;16(3):462-469.

5. Hoesch RE, Lin E, Young M, Gottesman RF, Altaweel L, Nyquist PA, Stevens RD. Acute lung injury in critical neurological illness. Crit Care Med 2012;40(2):587-593.

6. Treggiari MM, Hudson LD, Martin DP, Weiss NS, Caldwell E, Rubenfeld G. Effect of acute lung injury and acute respiratory distress syndrome on outcome in critically ill trauma patients. Crit Care Med 2004;32(2):327-331.

7. Treggiari MM, Bendjelid K, Yanez ND, Heidegger CP, Suter PM, Romand JA. Atrial and brain natriuretic peptide concentrations and the response to inhaled nitric oxide in patients with acute respiratory distress syndrome. J Crit Care 2010;25(1): 23-29. 